\title{
Beetles in Selected Barangays of Catarman, Northern Samar, Philippines
}

\author{
Jehosaphat C. Jazmin'1, Abel Alejandro U. Flores, Jr.² \\ University Research and Development Services, \\ College of Science Biology Department, Catarman, Northern Samar, Philippines
}

\begin{abstract}
How to cite this paper: Jehosaphat C. Jazmin | Abel Alejandro U. Flores, Jr. "Beetles in Selected Barangays of Catarman, Northern Samar, Philippines" Published in International Journal of Trend in Scientific Research and Development (ijtsrd), ISSN: 24566470, Volume-3 | Issue-3 , April 2019, pp.487-490, URL: http://www.ijtsrd.co $\mathrm{m} /$ papers/ijtsrd229 37.pdf

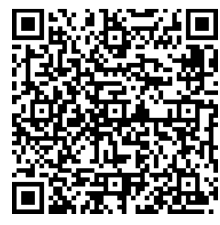

IITSRD22937
\end{abstract}

Copyright (C) 2019 by author(s) and International Journal of Trend in Scientific Research and Development Journal. This is an Open Access article distributed under the terms of the Creative Commons

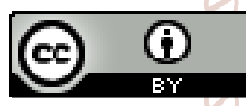
Attribution License (CC BY 4.0) (http://creativecommons.org/licenses/ by/4.0)

\section{INTRODUCTION}

In Haldane's day, estimates of the number of beetle species were in the tens of thousands. Currently, the estimates range to about 350,000 species, accounting for about 20 percent of all hexapod species. Their small size, an average length ranging from 4-5 millimeters, has ensured that their activities mostly go unnoticed, but sheer numbers of species, make them important members of all terrestrial and freshwater ecosystems, being important food items for numerous species of reptiles, birds, small mammals, and fish. Beetles are also important agricultural and forestry pests, with numerous species being injurious to crops, trees, and stored products. Their most important beneficial roles, as pollinators and as recyclers of nutrients, are activities which ensure the health of ecosystems (Ashworth, 2001).

Beetles have "sheathed" wings (elytra), for the past 285 million years, while their hind wings, made of membrane and does the actual "flying", are a later development (245 million years ago), at least for the $90 \%$ of beetle species in the suborder Polyphaga. Their hind wings are much bigger than their elytra, sometimes sticking out from under these covers when flying beetles land (Grimaldi and Engel, 2005).
The Philippine tiger beetle fauna presently includes 139 species, $120(86.3 \%)$ of which appear to be endemic to the archipelago, which makes the Philippines the seventh richest country of the world in absolute numbers of species, the fifth in percent number of endemic tiger beetle species (Cassola, 2011). A rapid survey of tiger beetles conducted by Anzano and Cabras (2016) in two protected landscapes of Davao Region reported a total of five $(62.5 \%)$ endemic species, of which $60 \%$ are Philippine endemics, while 2 (40\%) are endemic to Mindanao. Two species, Heptodonta lumawigi and Cylindera (Eugrapha) excisa, were first provincial records in Compostela Valley, raising its tiger beetle fauna from twelve to fourteen. Ecologic data were also presented for the species as well as the threats that they experience in both protected landscapes, providing baseline data of tiger beetles for both protected landscapes. Conservation measures should be conducted to preserve the tiger beetles. Strengthened implementation of protection in both protected landscapes against mining, illegal logging, slash and burn farming and human settlements should also be done (Anzano and Cabras, 2016). 


\section{OBJECTIVES OF THE STUDY}

Specifically, the study aimed to:

1. identify the different species of beetles in selected barangays of Catarman, Northern Samar;

2. determine the abundant species and the relative abundance of beetle species present in the study area; and,

3. describe the environmental factors that affect the

\section{Presence of beetles in the study area in terms of:}

3.1. Air temperature;

3.2. Soil temperature;

3.3. Habitat; and,

3.4. Vegetation (Grassland, forest, woodland, coconut trees, or rice field)

\section{METHODOLOGY}

This study was conducted in the Municipality of Catarman, Northern Samar, a first-class municipality and the capital town of Northern Samar, Philippines, subdivided into 55 barangays (Catarman Municipal Profile, 2016).

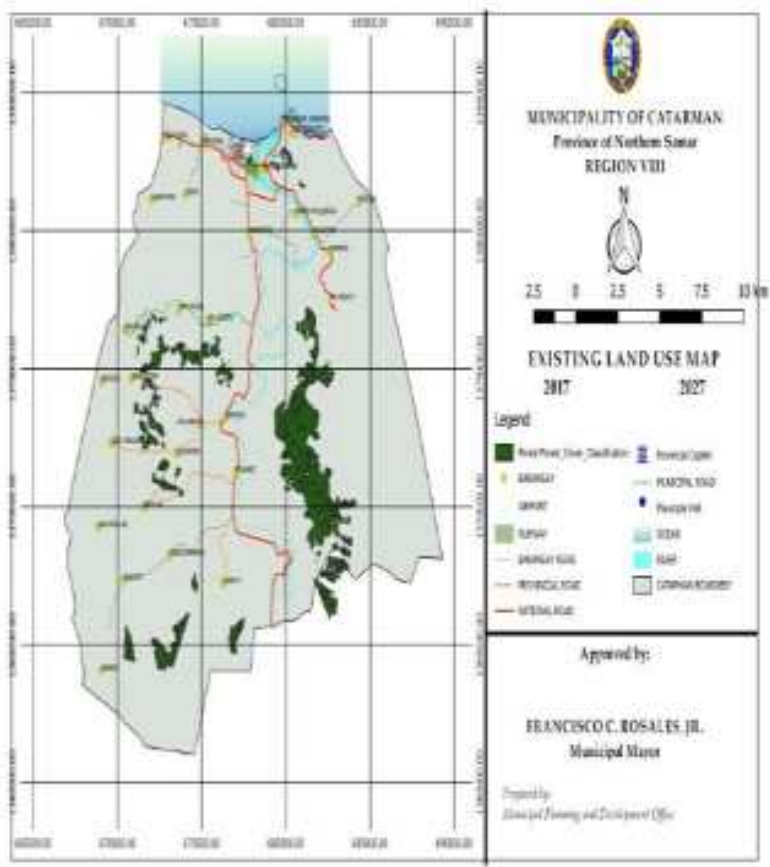

Floure 1. Map of Northern Samar

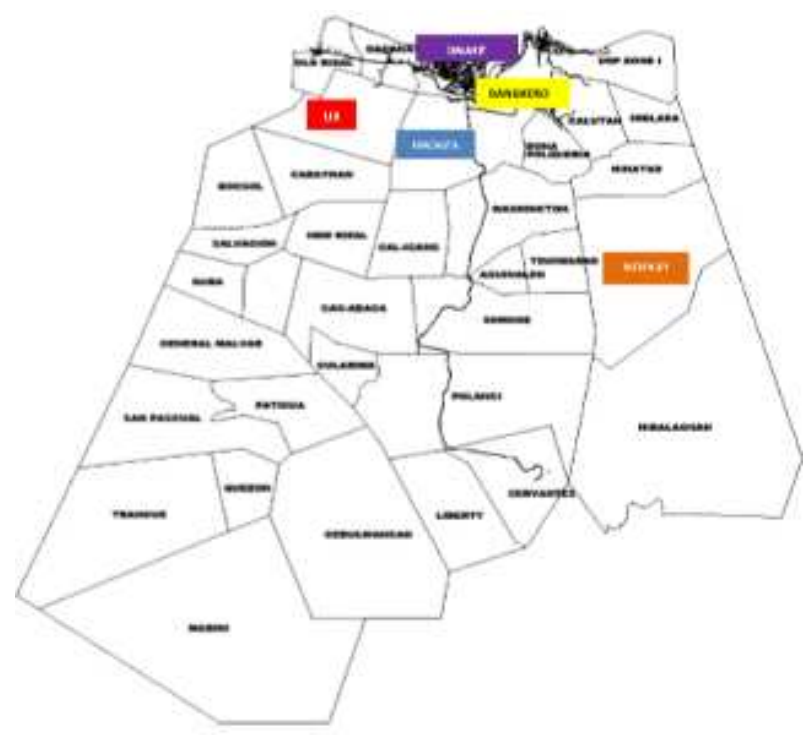

It used the descriptive method of research, purposively sampling and collecting beetle species using an insect net. Each species was identified, quantified, classified, and placed in a container for preservation purposes.

\section{RESULTS AND DISCUSSION}

From five sampling sites, represented by different barangays of Catarman, Northern Samar which were visited every weekend at daytime and nighttime, a total of seventeen (17) beetle species were collected, pre-identified by the researcher, and authenticated by an expert. These species belong to eleven (11) families, namely: Buprestidae, Brentidae, Cetoniidae, Cerambycidae, Coccinellidae, Chrysomelidae, Curculionidae, Elateridae, Lucanidae, Melolonthidae, and Scarabaeidae. The beetle species were, namely: Harmonia axyridis, Delphastus sp., Chrysochroa fulminans, Chrysochus sp., Aspidimorpha miliaris, Chalcosoma atlas, Aulacophora sp., Oryctes rhinoceros, Otiorhychus sp., Scyphophorus acupuntatus, Leucopholis irrorata, Diphucephala sp., Anoplophora sp., Heterorrhina sp., Nigidius amplicollis, Alaus sp., and Pachyrhynchus sp.

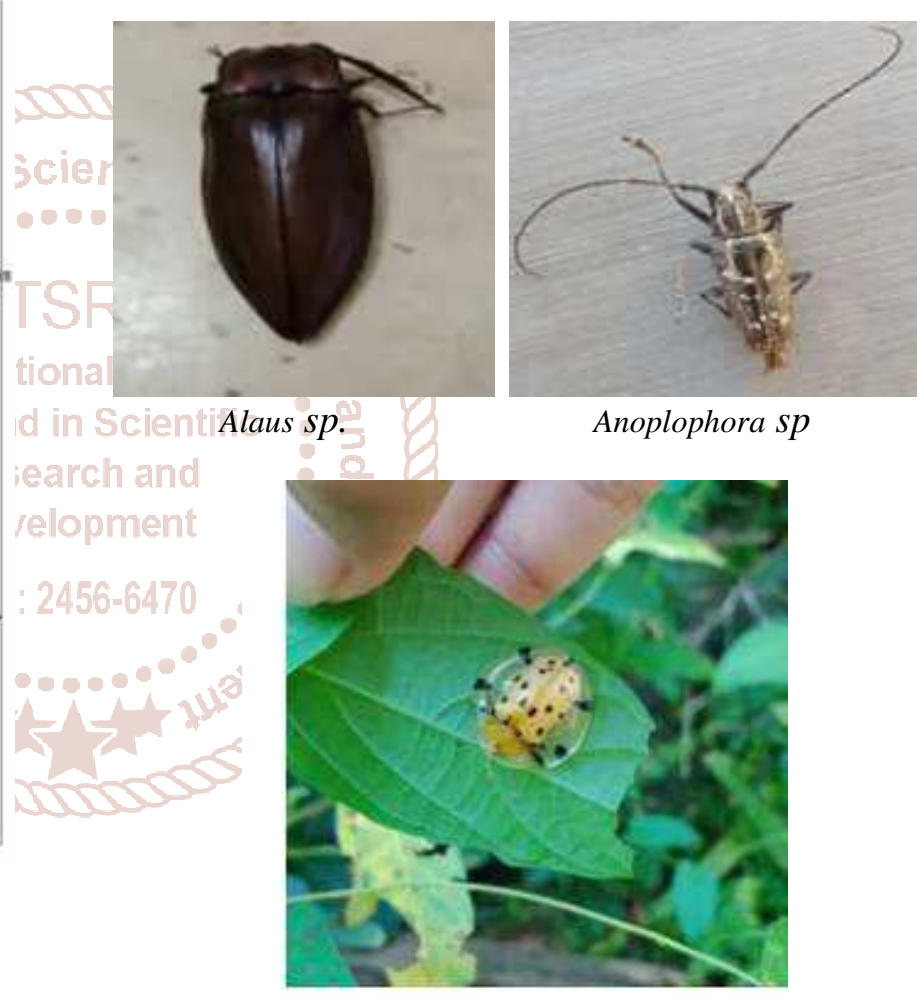

Plato 3. Aspidimorpha miliaris

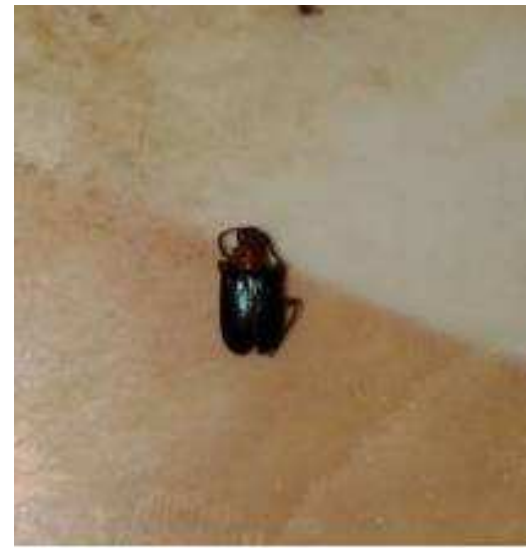

Plate 4. Aulacophora sp. 
International Journal of Trend in Scientific Research and Development (IJTSRD) @ www.ijtsrd.com eISSN: 2456-6470

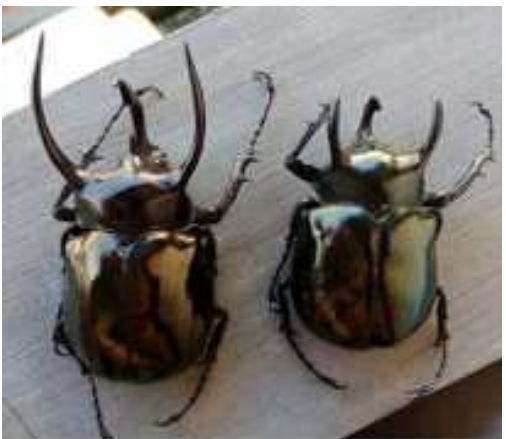

Plates b. Gristcosicome Aliys

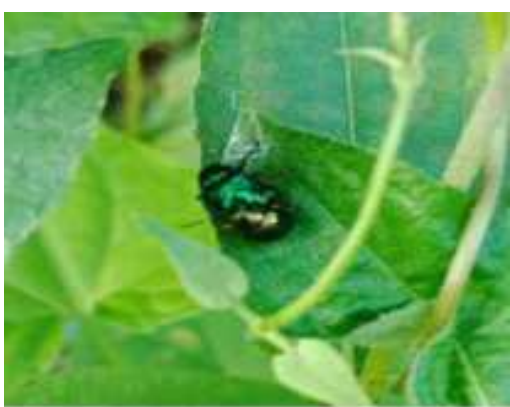

Plate 6. Chrysochus sp.

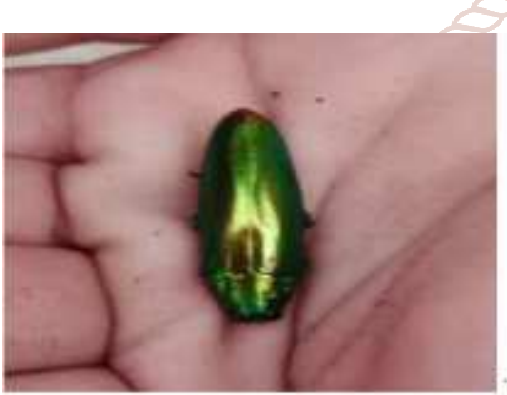

plata 7. Chryaochroa fulminana

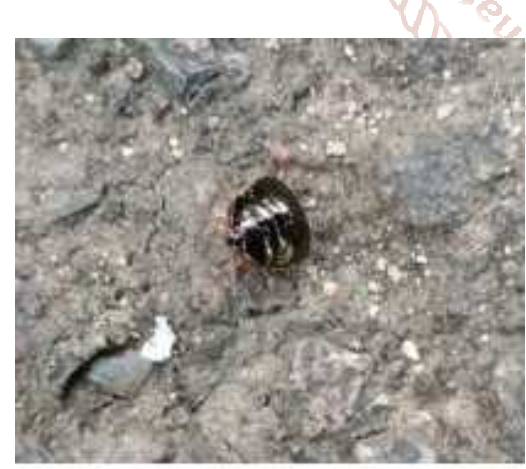

Plate 0 . DeIphastas so.

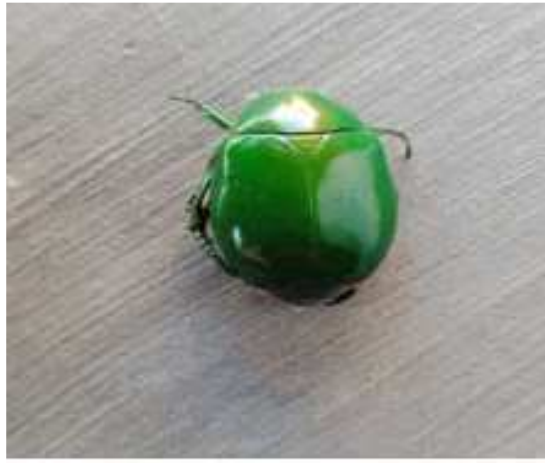

Plate 9. Diphucephala sp.

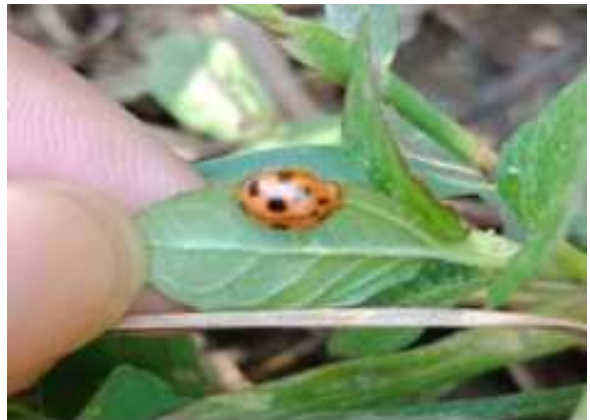

plate 10. Harmonia Axyrids

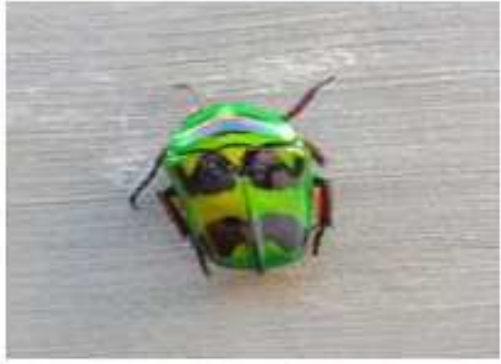
$117 \mathrm{n}$
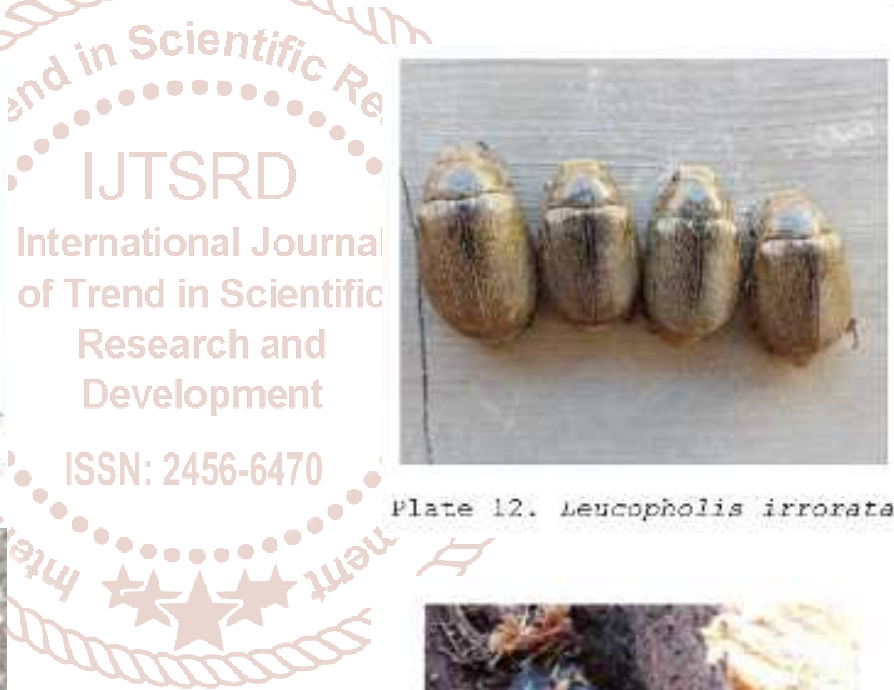

plate 12. Leucopinolis irrorata

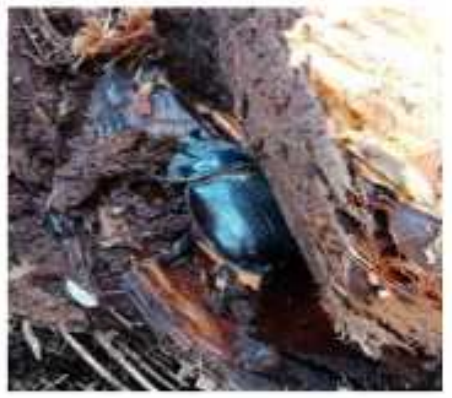

Plate 13. Oryotes rhtnoceros

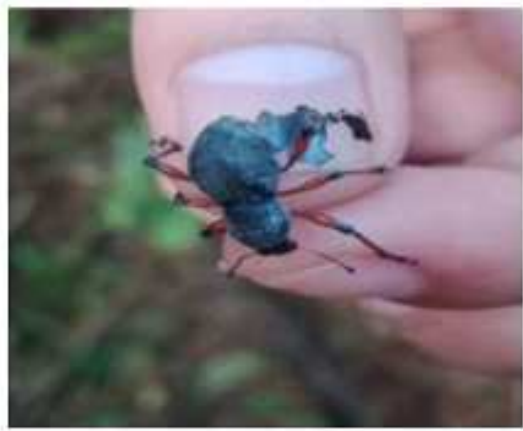

Plate 14. Otiorhyncus sp. 


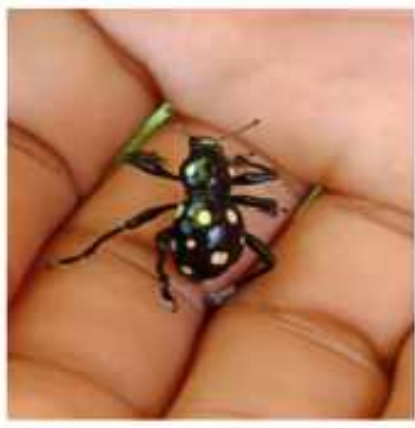

Plate 15. Pachyraynohug sp.

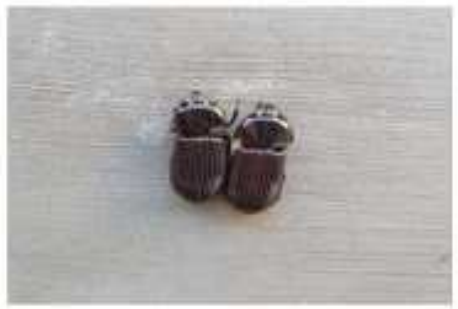

Plate 16. Nigidius ampileoilis

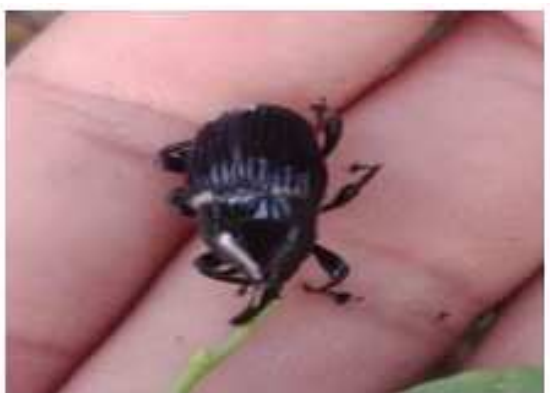

Plate 17. SCYphophoxus

Table 3. Prevailing Environmental factors in the study area

\begin{tabular}{|c|c|c|c|c|c|}
\hline \multirow{2}{*}{$\begin{array}{c}\text { Environnental } \\
\text { Paraneters }\end{array}$} & \multicolumn{5}{|c|}{ Sampling sites } \\
\cline { 2 - 6 } & 1 & 2 & 3 & 4 & 5 \\
\hline $\begin{array}{c}\text { Air } \\
\text { temperature }\end{array}$ & $28^{\circ} \mathrm{C}$ & $27^{\circ} \mathrm{C}$ & $28^{\circ} \mathrm{C}$ & $29^{\circ} \mathrm{C}$ & $29^{\circ} \mathrm{C}$ \\
\hline $\begin{array}{c}\text { Soil } \\
\text { temperature }\end{array}$ & $29^{\circ} \mathrm{C}$ & $28^{\circ} \mathrm{C}$ & $29^{\circ} \mathrm{C}$ & $28^{\circ} \mathrm{C}$ & $27^{\circ} \mathrm{C}$ \\
\hline
\end{tabular}

Table 4. Habitat \& Vegetation in the sampling sites

\begin{tabular}{|c|c|c|}
\hline SAMPIING SITE & HABITAT & VEGETATION \\
\hline Barangay Bangkerohan & Coconut trees & Grasses \\
\hline Baxangay Dalakit & woodland area & $\begin{array}{l}\text { Grasses, trees, } \\
\text { shrubs, }\end{array}$ \\
\hline Baxangay Iibjo & Rice field area & Grasses \\
\hline Baxangay Macagtas & Grassland area & Grasses and shrubs \\
\hline Barangay Mckingley & Forest area & $\begin{array}{l}\text { Grasses, herbs and } \\
\text { shrubs }\end{array}$ \\
\hline
\end{tabular}

\section{CONCLUSIONS AND RECOMMENDATIONS}

Based on the findings, it can be concluded that a diversity of beetle species was present in the study area, which implies that environmental were conducive for the beetles to thrive. Although the number of species collected were only a fraction of the total number of beetle species listed in the country, it is shown that there is a variety of species present. The researchers recommend that further studies on the influence of habitat types, vegetative cover, and other environmental parameters on the presence or absence of beetles in other barangays of Catarman, Northern Samar should be done to have a relatively complete baseline information about their existence in the locality. Further, conservation efforts should be strengthened by the LGU in order to conserve not only the beetle population in the study area but other organisms, both flora and fauna, as well.

\section{ACKNOWLEDGMENT}

The researchers would like to thank the following:

1. The College Administration

2. The Local Government Unit of Catarman, Northern Samar

3. The University Research and Development Services Unit

\section{LITERATURE CITED}

1. Ashworth, A. C., 2001. Perspectives on Quaternary Beetles and Climate Change. In: Gerhard, L. C., W. E. Harrison, and B. M.

2. Hanson (Eds.). Geological Perspectives of Global Climate Change. American Association of Petroleum Geologists Studies in Geology \# 47, Tulsa, Oklahoma.

3. Cabras, Analyn and Jurgen Weisner, Tiger Beetles (Coleoptera: Carabidae: Cicindelinae) of Mainit Hotspring and Mati Protected Landscape, Mindanao with Notes on their Ecology and Threats, International Research Journal of biological Sciences, Vol. 5 (9), 16-21, September, 2016.

4. Cassola, F. 2011. Studies of Tiger Beetles: A new Calomera species from Mindanao, Philippines (Coleoptera, Cicindelidae). Spixiana 34 (1): 129-131.

5. Department of the Interior and Local Government, Catarman, Northern Samar, 2017.

6. Pacific Pests and Pathogens Factsheet, 2016, Australian Center for International Agricultural Research. 